\title{
Koncepcje reform Unii Europejskiej i jej stanowisko wobec integracji Europy
}

\section{Wprowadzenie}

Pisząc „,koncepcje reform Unii Europejskiej (UE)”, mam na myśli przede wszystkim projekty i stanowiska, które w tej sprawie w ostatnich latach zgłaszały i nadal zgłaszają jej główne organy, a szczególnie Komisja Europejska i Parlament Europejski. Wespół z Radą Europejską i Radą UE odpowiadają one nie tylko za funkcjonowanie Unii, ale także za integrację Europy dziś i w przyszłości. Takich różnych projektów, koncepcji reform, strategii, deklaracji i propozycji w sprawie „naprawy” UE, mniej lub bardziej dopracowanych, realistycznych lub futurologicznych w Brukseli opracowano już wiele. Natomiast niewiele z nich zostało wprowadzonych w życie. W tym też - moim zdaniem - tkwi przyczyna słabości UE i źródło jej licznych kryzysów i problemów.

Celem tego opracowania jest pokazanie Unii Europejskiej dziś, tzn. 15 lat po wielkim rozszerzeniu w 2004 roku i zarysowanie jej przyszłości w świetle różnych unijnych dokumentów, dotyczących reform UE i jej perspektyw. Przedmiotem niniejszego opracowania jest więc analiza obecnej kondycji UE, czyli stanu politycznego, społecznego i gospodarczego oraz omówienie jej perspektyw w XXI wieku, ze szczególnym uwzględnieniem szans i zagrożeń dla tego bezprecedensowego projektu.

W niniejszym opracowaniu stawiam kilka dyskusyjnych tez i hipotez, m.in., że UE po 15-tu latach od wielkiego rozszerzenia, pod wieloma względami to zupełnie inna Unia, niż ta do której wstępowaliśmy razem z dziewięcioma innymi państwami 1 maja 2004 roku. Kolejna teza to stwierdzenie, że rozszerzenie UE o 10 nowych państw, w tym osiem krajów dawnego bloku sowieckiego było błędem. UE nie była bowiem wystarczająco przygotowana na takie bezprecedensowe rozszerzenie. Było ono determinowane bardziej racjami politycznymi i międzynarodowymi, a nie uwzględniało realiów społecznych i gospodarczych w tych państwach. Po przedwczesnym przyjęciu przez Unię Europejską wspólnej waluty euro, co - moim zdaniem - także było błędem, był to kolejny poważny błąd i zarazem źródło wielu kryzysów w Unii, z których nie udało się jej wyjść do dnia dzisiejszego. Zostały one tylko zażegnane i wkrótce uderzą z całą mocą. To kolejna hipoteza niniejszego opracowania. Moim zdaniem, 1 maja 2004 roku należało do UE przyjać tylko 3, maksymalnie 5 państw najlepiej do akcesji wówczas przygotowanych, tj. Czechy, Maltę, Polskę, Słowację i Węgry. Tak, jak to miało miejsce w przypadku ostrożnego poszerzania NATO. W dalszej kolejności należało do UE ostrożnie przyjmować następne postkomunistyczne państwa, stawiając im jednak wysokie wymagania eko- 
nomiczne, polityczne, społeczne, prawne i inne, tak jak to zostało zapisane w traktacie z Maastricht i kolejnych traktatach rewizyjnych.

W opracowaniu tym spróbuję też odpowiedzieć na kilka pytań, m.in. czy UE nadal znajduje się w kryzysie, a zwłaszcza w trudnej sytuacji gospodarczej i społecznej, co delegitymizuje ją na arenie międzynarodowej, jak twierdzi wielu badaczy i ekspertów? Ponadto, dlaczego UE wciąż unika nowych reform oraz jej dalszego pogłębiania i poszerzania? Czy była to jedna z głównych przyczyn brexitu oraz czy i kiedy do niego dojdzie? Czy przyznanie krajom UE większej swobody w zakresie polityki gospodarczej i socjalnej, przy zachowaniu podstawowej polityki wspólnotowej, jak choćby wspólny rynek, mogło zatrzymać Wielką Brytanię w UE oraz ostudzić „exitowy" zapał innych krajów? Notabene, takie rozwiązania proponował premier David Cameron, który w liście do przewodniczącego Rady Europejskiej Donalda Tuska zawarł nie tylko postulat ograniczenia zasiłków imigrantom z innych państw UE, ale także apelował o pilny powrót Unii do jej wolnorynkowych korzeni podkreślając, że: „Ciężar istniejących regulacji jest nadal zbyt wielki. Wielka Brytania chciałaby zatem zobaczyć konkretny cel w postaci cięcia administracyjnych obciążeń działalności gospodarczej. Unia Europejska musi także uczynić więcej, aby spełnić swoje zobowiązania dotyczące swobodnego przepływu kapitału, towarów i usług". Ponadto zwracał on uwagę na bałagan w unijnych pomysłach, który przyczynia się do tego, że prorynkowe pomysły Brukseli nie są realizowane: „Musimy zebrać razem wszystkie propozycje legislacyjne, obietnice i porozumienia w zakresie wspólnego rynku, handlu i ograniczenia regulacji oraz przekształcić je w jasne, długoterminowe zobowiązania mające na celu zwiększenie konkurencyjności i produktywności Unii Europejskiej oraz kreację wzrostu i miejsc pracy dla wszystkich" (Czepiel, 2016, s. 6). Niestety, w lutym 2016 roku Rada Europejska apele te potraktowała po macoszemu, a unijni przywódcy zapowiedzieli, że stworzą specjalny program mający wyeliminować nadmierną biurokrację w Unii, ale do dnia dzisiejszego wciąż tego nie uczyniono (Fiszer, 2018, s. 49-50).

Poza tym spróbuję tutaj odpowiedzieć na pytanie, jakie pozytywne i negatywne skutki dla UE będzie miał brexit, jeśli w ogóle do niego dojdzie? Brexit - moim zdaniem - jeśli do niego dojdzie, będzie miał dla UE przede wszystkim skutki negatywne. Uważam, że dla UE i Wielkiej Brytanii oraz dla Polski brexit będzie wręcz katastrofą. Przyniesie więcej szkód niż korzyści, o czym już dziś mówią różne raporty i analizy przygotowane przez brytyjskich i unijnych ekspertów. Brexit może być początkiem końca UE, czyli doprowadzić ją do rozpadu, albo stanie się ona tylko strefą wolnego handlu (Brexit to wyprawa w nieznane, 2017, s. 12). W „Orędziu o stanie Unii 2017” z 13 września 2017 roku przewodniczący Komisji Europejskiej Jean-Claude Juncker napisał: „29 marca 2019 r. Wielka Brytania wystąpi z Unii Europejskiej. Będzie to smutny i tragiczny moment. Zawsze będziemy tego żałowali. Musimy jednak uszanować wolę Brytyjczyków. Będziemy iść naprzód, musimy iść naprzód, bo Brexit to nie wszystko. Brexit nie jest przyszłością Europy" (President Jean-Claude Juncker's State of the Union Address, 2017). Póki co, do brexitu nie doszło i nie wiadomo czy w ogóle do niego dojdzie i kiedy to nastąpi. Teoretycznie Wielka Brytania do 31 października 2019 roku powinna wyjść z Unii Europejskiej. Kandydat na nowego premiera Wielkiej Brytanii Boris Jonson obiecuje, że Wielka Brytania będzie poza Unią przed 31 października, na podstawie wynegocjowanej z Brukselą nowej ,umowy rozwodowej” lub 
bez niej (Czarnecki, 2019, s. 9; Bielecki, 2019, s. A6). Natomiast lider Partii Pracy Jeremy Corbon obiecuje dziś, że jego ugrupowanie poprze drugie referendum w sprawie umowy brexitowej i mówi wprost: „niech naród zadecyduje o przyszłości kraju” (,Rzeczpospolita, 2019, s. 3).

Uważam, że brexit zwiększy rolę Francji i Niemiec w UE. Natomiast Polska może ponownie znaleźć się między potężnymi Niemcami i Rosją, gdyż wszystko wskazuje na to, że po brexicie rola Niemiec w UE i w ogóle w Europie gwałtownie wzrośnie, a jeszcze bardziej wzrosłaby po rozpadzie Unii. Brexit doprowadzi bowiem do zachwiania politycznej równowagi, jaką w pewnym stopniu stanowiła Wielka Brytania dla niemiecko-francuskiego tandemu, a biorąc pod uwagę obecne problemy polityczne, społeczne i gospodarcze Francji sprawi, że to RFN stanie się niekwestionowanym liderem UE. Fakt ten nie musi jednak oznaczać, że Niemcy od razu staną się zagrożeniem dla Polski, UE i bezpieczeństwa Europy, ale w przyszłości tego wykluczyć nie można. Zwłaszcza, gdyby doszło do zacieśnienia i rozwoju współpracy niemieckorosyjskiej. Swoje strategiczne cele Moskwa zdefiniowała już dawno temu. W odniesieniu do UE i w ogóle Europy są to: dezintegracja UE poprzez podsycanie sporów między państwami, podgrzewanie nastrojów antyamerykańskich, żeby ograniczać wpływy Stanów Zjednoczonych w Europie, utrzymanie i poszerzenie wpływów politycznych i gospodarczych, czemu ma służyć sukcesywne budowanie prorosyjskiego lobby, utrzymanie kontroli nad Białorusią i przywrócenie kontroli nad Ukrainą, destabilizacja państw bałtyckich i Polski celem osłabienia wschodniej flanki NATO i inne (Fiszer, 2018, s. 39-55; Jak refren..., 2019, s. A4 i A5). Póki co, w interesie Niemiec jest, żeby Polska była bezpieczna i umacniała wszechstronne relacje tak ze Wschodem, jak i Zachodem. Niemcy - jak pisze politolog z Stiftung Wissenschaft und Politik, specjalizujący się w kwestiach Europy Środkowej i UE Kai Olaf Lang, również „chcą utrzymać rozmowy z Rosją i nie dać Moskwie kolejnych pretekstów do zaostrzenia retoryki i wzmocnienia zbrojeń. Musimy uważać, by w polsko-niemieckich relacjach nie było takiego przerzucania się: wy budujecie gazociąg Nord Stream 2, a w końcu chcecie zniesienia sankcji na Rosję, a wy rozmawiacie za naszymi plecami, by wzmocnić swoje relacje z USA, co długoterminowo może zwiększyć ryzyko nowego wyścigu zbrojeń w regionie. Do tego przydałby się wzmocniony dialog polsko-niemiecki o polityce bezpieczeństwa i sprawach strategicznych. [...] Po drugie, jeśli Polska będzie grała zbyt mocno kartą amerykańską, może to doprowadzić do kolejnych rozczarowań i napięć, np. z Francją i w końcu też z Niemcami. [...] Polska powinna wzmocnić swój wymiar europejski i pokazać podmiotowość wobec Waszyngtonu" (Lang, 2019, s. A3).

Natomiast pozytywnym efektem brexitu może być podjęcie jednak głębokich reform systemowych w UE, m.in. reform politycznych, przekształcających ją w federację suwerennych państw narodowych lub będzie to Unia o różnych prędkościach, albo tzw. zróżnicowanej integracji. Notabene, te dwa ostatnie rozwiązania dla Polski również będą niekorzystne, a więc trudne do przyjęcia. Dała temu wyraz m.in. Beata Szydło, czołowy polityk partii Prawa i Sprawiedliwości stwierdzając, że: „Z naszej perspektywy najważniejszym celem jest zapobieżenie scenariuszowi podziału na UE kilku prędkości. [...] Naszym zadaniem jest zgromadzenie grupy krajów, które zadbają o interesy naszego regionu" (Osiecki, Żółciak, 2019, s. A3). 
Brexit pokazuje dziś, że to, co zrobili Brytyjczycy, nie jest jednak dobrym pomysłem dla Europy. Zdając sobie z tego sprawę, Polska pod koniec maja 2019 roku przesłała do Brukseli własną propozycję reform UE, które - w jej mniemaniu - mogłyby doprowadzić do odbudowy zaufania społecznego do Wspólnoty i przyczynić się do dalszej integracji Europy. W dokumencie tym Polska zwróciła uwagę na sześć wyzwań, od których zależeć będzie przyszłość zjednoczonej Europy. Są to polityka migracyjna i obronna, ochrona konkurencji na wspólnym rynku i budowa w jego ramach jednolitego rynku cyfrowego, a także powstrzymanie zmian klimatycznych i wzmocnienie demokratycznej legitymizacji Brukseli (Bielecki, 2019, s. A7). Na temat tych propozycji szerzej piszę w drugiej części niniejszego opracowania.

\section{Unia Europejska dziś i jej problemy}

Wraz z utworzeniem Unii Europejskiej, czyli specyficznego związku demokratycznych, suwerennych państw, który ma tylko te kompetencje, które dobrowolnie przekazały jej państwa członkowskie, wydawało się, że dotychczasowe wizje Europy ponadnarodowej, zjednoczonej gospodarczo, politycznie i ideowo, a tym samym żyjącej $\mathrm{w}$ pokoju, dobrobycie i bezpieczeństwie, zostaną wreszcie urzeczywistnione w praktyce stosunków międzynarodowych. Niestety, te marzenia Europejczyków i nadrzędne cele europejskiej integracji wciąż są in statu nascendi, a droga do zjednoczonej i bezpiecznej Europy jest jeszcze daleka. Nie ulega natomiast wątpliwości, że traktat z Maastricht i utworzona na jego mocy Unia Europejska otwarły nowe możliwości przyśpieszania procesów integracyjnych w Europie, które nie zostały jednak maksymalnie wykorzystane. Unia Europejska de jure opiera się na wartościach poszanowania godności osoby ludzkiej, wolności, demokracji, równości, państwa prawnego, jak również poszanowania praw człowieka, w tym praw osób należących do mniejszości. Wartości te są wspólne państwom członkowskim w społeczeństwie opartym na pluralizmie, niedyskryminacji, tolerancji, sprawiedliwości, solidarności oraz na równości kobiet i mężczyzn. Niestety, o wartościach europejskich zapisanych w artykule 2 traktatu o Unii Europejskiej przez ostatnie 15 lat dyskutowano niewiele. Wszyscy bowiem byli przeświadczeni o bezsporności tych zapisów, a zarazem stali na stanowisku, że najważniejszymi dla UE problemami są kwestie ekonomiczne i walka o pieniądze z unijnego budżetu (Pełczyńska-Nałęcz, 2019, s. 7).

Dziś widać wyraźnie, że Unia i zjednoczona Europa powinny być oparte na systemie wartości, który z jednej strony będzie prowadził do zmniejszenia tego, co dziś nazywamy deficytem demokracji, wzmocnienia praworządności, równości i wolności, a z drugiej umożliwi państwom średnim i małym odgrywanie takiej roli, na jaką zasługują, a na pewno roli nieporównywalnie większej, niż gdyby zostały one poza taką dobrowolną wspólnotą państw, jaką jest Unia Europejska. Dlatego też UE musi nadal być otwarta na pozostałe kraje, zwłaszcza z Europy Środkowo-Wschodniej, które z różnych względów nie są jeszcze jej członkami. Istniejącą wspólnotę gospodarczą w UE należy uzupełnić wspólnotą bankową, polityczną, wojskową, naukowo-techniczną i kulturową. Tylko wówczas stanie się możliwe zbudowanie europejskiego społeczeństwa obywatelskiego, które będzie gwarancją dalszego rozwoju demokratycznej UE 
i bezpiecznej, wolnej od ksenofobii, nacjonalizmu i konfliktów międzynarodowych oraz wojen Europy (Fiszer, 2016, s. 97-124; Ágh, 2016, s. 123-141). Wychodząc naprzeciw tym oczekiwaniom, w styczniu 2019 roku Parlament Europejski zdecydował o uzależnieniu dostępu do unijnych funduszy od stanu praworządności w państwach członkowskich oraz o stworzeniu Programu Obywateli, Równości, Praw i Wartości (PPW), który ma wspierać prodemokratyczne działania Europejczyków. Regulacje te mają dla Unii znaczenie strategiczne. Podważanie wspólnych zasad, zwłaszcza w sferze państwa prawa, stanowi dziś jedno z największych zagrożeń dla trwałości Wspólnoty. Zasady PPW zostały już zaakceptowane przez Radę Unii Europejskiej. Zgoda Rady na wielkość funduszy i mechanizm warunkowości budżetowej z pewnością będą częścią nasilającej się rozgrywki wokół nowego budżetu UE na lata 2021-2027. Dlatego też organizacje obywatelskie i prodemokratyczne siły polityczne powinny teraz zrobić wszystko co możliwe, aby sprawa ta nie zniknęła w wielkim unijnym „kotle negocjacyjnym" (Pełczyńska-Nałęcz, 2019, s. 2).

O skuteczności powyższych, ciekawych i niezbędnych dla dalszego rozwoju UE rozwiązań zadecyduje jednak sposób ich wdrażania w życie. Przy wprowadzaniu do praktyki Programu Praw i Wartości konieczne jest wyjście poza myślenie wyłącznie w kategoriach technokratycznych procedur. Jak pisze Katarzyna Pełczyńska-Nałęcz: „Istotne jest tu przeciwstawienie się stereotypowemu postrzeganiu PPW jako «funduszu dla lewicy i unijnych lojalistów». [...] Wreszcie w dłuższej perspektywie do efektywnego zastosowania nowych rozwiązań potrzebne jest budowanie poczucia rzeczywistej wspólnoty wartości wśród zwolenników zjednoczonej Europy" (Pełczyńska-Nałęcz, 2019, s. 2).

Nie ulega wątpliwości, że Unia Europejska potrzebuje dziś głębokich reform, a może nawet nowego traktatu rewizyjnego. Pojawiają się bowiem nowe zagrożenia, których skala do tej pory była nieznana. Diagnoza ta stała się obowiązującym hasłem obchodów sześćdziesięciolecia traktatów rzymskich, które odbyły się w marcu 2017 roku. W przededniu tego wydarzenia pojawiło się wiele raportów, propozycji zmian i scenariuszy na przyszłość, firmowanych przez instytucje unijne i niezależne instytuty. Ich główna teza była wspólna - zreformować i usprawnić Unię Europejską oraz uczynić ją odporną na kryzysy i bardziej otwartą na obywateli i ich problemy. Bruksela - pod wpływem państw członkowskich, a zwłaszcza Francji i Niemiec oraz państw Grupy Wyszehradzkiej (Fiszer, 2018, s. 208-234; Czyż, 2018) - proponowała, aby maksymalnie wykorzystać możliwości, jakie w tym zakresie zapisano w traktacie z Lizbony. Wskazywała na potrzebę zmiany w formie głosowania w Radzie Unii Europejskiej, zwiększenie aktywności Parlamentu Europejskiego na rzecz nowych inicjatyw ustawodawczych oraz pogłębienie jego funkcji kontrolnej. W rezolucji z 16 lutego 2017 roku wskazano na pogłębiające się niezadowolenie z funkcjonowania UE w obecnym kształcie i na potrzebę koniecznych zmian oraz niezbędnych reform, aby Unia odbudowała swój autorytet i prestiż (Rezolucja Parlamentu Europejskiego, 2017).

O potrzebie zmiany traktatu z Lizbony mówią od dłuższego czasu unijni politycy i przywódcy państw członkowskich, m.in. prezydent Francji Emmanuel Macron. Moim zdaniem jest to nieuniknione w przyszłości, ale obecnie istnieje obawa przed otwieraniem unijnych traktatów, szczególnie w Niemczech. Dominuje pogląd, że róż- 
nice i napięcia między krajami UE sprawiłyby, że nie udałoby się osiągnąć zgody co do kierunku zmian i dalszego jej rozwoju (Nizinkiewicz, 2019, s. A5).

Wśród unijnych dokumentów poświęconych reformom i przyszłości UE - według mnie - na szczególną uwagę zasługuje „Biała księga w sprawie przyszłości Europy. Refleksje i scenariusze dotyczące przyszłości UE-27 do 2025 roku” (Biała Księga w sprawie przyszłości Europy, 2017). Szczegółowo o tym i innych dokumentach dotyczących perspektyw i reform Unii Europejskiej piszę w drugiej części niniejszego opracowania. Tutaj chciałbym tylko przytoczyć słowa z przedmowy do tej „Białej księgi” szefa Komisji Europejskiej Jeana-Claude Junckera: „Niniejsza biała księga stanowi wkład Komisji Europejskiej w ten nowy rozdział projektu europejskiego. Chcemy zainicjować proces, w którym Europa wytyczy własną drogę naprzód. [...] Stoją przed nami poważne wyzwania dotyczące bezpieczeństwa i dobrobytu naszych mieszkańców oraz przyszłej roli Europy w coraz wyraźniej zarysowanym wielobiegunowym świecie. Zjednoczona Europa skupiająca 27 państw musi wziąć los we własne ręce i zdecydować, jak ma wyglądać jej przyszłość” (Biała Księga w sprawie przyszłości Europy, 2017, s. 3).

Unia Europejska musi wyciągnąć nauki z populistycznego buntu, zanim będzie za późno na przemyślenie projektu europejskiego tak, by mógł on odzyskać swoją społeczną i międzynarodową legitymację. W tym przypadku hasło Emmanuela Macrona „Europe qui protége” może być odpowiednim modelem dla przyszłej Unii Europejskiej, która musi stać się bardziej demokratyczna i zrozumiała dla obywateli. Dziś wielu polityków i ekonomistów, m.in. laureat Nagrody Nobla Joseph Stiglitz podkreśla, że celem priorytetowym UE powinna stać się poprawa pomyślności zwykłych ludzi (Stiglitz, 2016).

Hasło UE bardziej prospołecznej i demokratycznej dominowało w programach wielu partii politycznych podczas wyborów do Parlamentu Europejskiego w dniach 23-26 maja 2019 roku. W tegorocznej kampanii wyborczej do Parlamentu Europejskiego prym wiedli nacjonaliści i populiści, a w cieniu pozostali eurooptymiści i realiści. Popularnością cieszyły się też hasła antyimigracyjne i UE jako „ojczyzna suwerennych państw". W rezultacie sporo mandatów do europarlamentu zdobyli kandydaci z partii radykalnych (prawicowych i lewicowych), a znacznie mniej z tradycyjnych partii demokratycznych, na przykład w Belgii, Francji, Niemczech, we Włoszech i Polsce. Jeszcze przed wyborami do Parlamentu Europejskiego wielu ekspertów liczyło się $\mathrm{z}$ istotnym wzrostem znaczenia na europejskiej scenie politycznej niechętnych pogłębianiu integracji ,partii protestu” w rodzaju francuskiego Zjednoczenia Narodowego Marine Le Pen oraz włoskiej Ligi Północnej premiera Matteo Salviniego. Tak się jednak nie stało. Pod względem układu sił politycznych nowy Parlament Europejski nie będzie różnił się radykalnie od obecnego, a proeuropejskie ugrupowania będą nadal miały tam większość. Co prawda, dwa największe centrowe ugrupowania, Europejska Partia Ludowa (EPP) i Partia Europejskich Socjalistów (PES), straciły większość w PE, ale jeśli stworzą koalicję z należącym również do głównego nurtu europejskiej polityki Związkiem Liberałów i Demokratów w Europie (ALDE), utrzymają kontrolę. Dzięki temu proeuropejskie i prospołeczne wizje i propozycje Komisji Europejskiej i Rady Europejskiej powinny nadal cieszyć się aprobatą eurodeputowanych. W praktyce to może oznaczać odnowioną legitymację PE, a może nawet całego projektu in- 
tegracji europejskiej (Siemionczyk, 2019, s. A17; Słojewska, 2019a, s. A9; Słojewska, 2019b, s. A6; Kolonko, 2019, s. A3).

W świetle teorii realistycznej, Unia Europejska (UE) nie jest państwem, ale jest podmiotem prawa międzynarodowego i podmiotem stosunków międzynarodowych. Jest dobrowolnym związkiem suwerennych i demokratycznych państw, specyficzną organizacją międzynarodową. Unia Europejska w świetle teorii neofunkcjonalnej jest samonapędzającym się mechanizmem, którego istota polega na tym, że każdy etap jej rozwoju pociąga za sobą konieczność dalszych kroków (spillover), czyli zwiększania jej kompetencji (pogłębianie integracji). Prowadzi to do stałych napięć wywoływanych zakresem i tempem zmian, definiowaniem narodowych interesów oraz pojmowaniem demokracji i suwerenności. Jest to przede wszystkim problem polityczny, a w mniejszym stopniu prawny. W relacjach międzynarodowych nie ma jednak i zapewne długo nie będzie światowego parlamentu, sądów czy rządu. Powstanie tego typu instytucji możliwe jest tylko za traktatową zgodą wszystkich państw, co zresztą ma miejsce w Unii Europejskiej, ale tylko w ograniczonym rzeczowo i geograficznie zakresie (Finkelstein, 1995, s. 368; Czaputowicz, 2007, s. 354-358).

Natomiast z perspektywy teorii gier (gry wielopoziomowej) Unia jest siłą wewnętrznie skonfliktowaną, gdyż rządy państw członkowskich są uzależnione od narodowych aktorów i w związku z tym mają odmienne postulaty odnośnie jej polityki wewnętrznej i zagranicznej. Jest to jedna z wielu przyczyn kryzysów, które od lat paraliżują działalność Unii Europejskiej i hamują integrację Europy. W efekcie tego w UE mamy dziś do czynienia z megakryzysem, na który składają się: kryzys finansowo-gospodarczy, kryzys aksjologii, kryzys zwany „deficytem demokratycznym”, kryzys integracji Europy, kryzys imigracyjny, kryzys przywództwa i kryzys spowodowany Brexitem (Fiszer, 2018, s. 54-78; Wojtaszczyk, Nadolska, 2015). Coraz wyraźniej ujawnia się brak jedności i solidarności wśród państw UE. Po 67 latach integracji, poczynając od utworzonej w 1952 roku Europejskiej Wspólnoty Węgla i Stali (EWWS), Europie zabrakło spoiwa oraz klarownej wizji jej dalszego rozwoju i miejsca w nowym ładzie globalnym, który wciąż jest in statu nascendi. Narastają głębokie podziały i kontestowana jest idea europejskiej solidarności i spójności, a tym samym maleje skuteczności UE jako aktywnego gracza na arenie międzynarodowej (Zielonka, 2014, s. 27-32; Schulz, 2014). W świetle dramatycznych wydarzeń m.in. w Kijowie, na Krymie i w Donbasie, a także w Syrii, Iraku oraz po ostatnich zamachach m.in. w Paryżu, Nicei, Berlinie i Sztokholmie wyraźnie uwidoczniły się liczne mankamenty Unii Europejskiej oraz uległ osłabieniu jej prestiż na świecie. Unia Europejska stanęła w obliczu wielu wyzwań politycznych, gospodarczych i społecznych, które wymuszają modernizację jej struktur oraz mechanizmów zarządzania i podejmowania decyzji. Szczególnie niebezpieczny i dotkliwy w skutkach, zarówno dla UE, jak i jej państw członkowskich - zwłaszcza tych należących do strefy euro - okazał się światowy kryzys finansowy. Ukazał polityczną słabość Unii, wymuszając pytanie o jej spoistość i solidarność. Amerykański ekonomista, noblista Michael Spence twierdzi, że strefa euro ledwo zipie, bo zaszkodziła jej globalizacja, długi i przestarzałe wewnętrzne prawodawstwo. Podkreśla, że Unia pilnie potrzebuje głębokich reform i większej unifikacji w kwestii fiskalnej, finansowej, bankowej oraz zwiększenia dynamiki inwestycji 
wzajemnych, mobilności kapitału, większych inwestycji w gospodarkę opartą na wiedzy (Stodolak, 2017, s. 6). Podobnie twierdzi wielu innych ekonomistów i ekspertów, m.in. profesor Markus C. Kerber z Uniwersytetu Technologicznego w Berlinie, który mówi wprost, że: „Gdy unia walutowa powstawała, Komisja Europejska oceniała, że przyspieszy ona konwergencję gospodarczą krajów UE. Tymczasem różnice w poziomie rozwoju zaczęły rosnąć. Stało się tak, bo dla niektórych - zwłaszcza Niemiec i Holandii - euro jest walutą za tanią, a dla innych - np. Grecji i Włoch - za silną. W tym sensie Niemcy na euro korzystają: słaba waluta ułatwia naszym firmom eksport. Ale ta korzyść jest niebezpieczna, bo zaburza konkurencję. [...] Strefa euro nie jest już żadną unią walutową, tylko unią szantażystów. Władze w Berlinie co chwila słyszą, że albo zgodzą się na kolejne kredyty, na wspólną odpowiedzialność za długi, albo unia upadnie. To podły szantaż” (Siemionczyk, 2019, s. A27).

W pełni zgadzam się z tymi opiniami. UE, aby mogła się rozwijać, obok unii gospodarczej i walutowej, musi stać się unią polityczną i społeczną. Potrzebuje nowego impulsu integracyjnego i nowej, atrakcyjnej wizji, która znowu zjednoczy Europę i zapewni jej godziwe miejsce w nowym porządku światowym, a jej obywatelom zapewni wolność, demokrację i dobrobyt. Pod koniec 2018 roku wiceprzewodniczący Komisji Europejskiej Andrus Ansip mówił: „Musimy być zjednoczeni i połączyć siły, aby chronić nasze demokracje przed dezinformacją. Byliśmy świadkami prób ingerowania w wybory i referenda, a dowody wskazują na to, że głównym źródłem tych kampanii była Rosja". Ta bezprecedensowa wypowiedź pokazuje, że temperatura dyskusji i dynamika zmian w Europie nie są do końca odzwierciedleniem rzetelnej wiedzy i chłodnej oceny faktów (Co Polacy myśla o Unii Europejskiej, 2019, s. 2).

Unia Europejska stoi dziś przed trudnym i niezmiernie istotnym dylematem: dalszy rozwój i pogłębianie integracji czy ograniczenie jej, spłycenie, a w konsekwencji zmniejszenie znaczenia na arenie międzynarodowej. Ważne decyzje, które nie mogą być odłożone na później dotyczą kwestii dziś strategicznych, takich jak: tempo rozszerzenia Unii, przyszłość rynku wewnętrznego, bezpieczeństwo energetyczne, problemy demograficzne, w tym związane z migracją ludności i uchodźcami, bezpieczeństwo obywateli oraz zagwarantowanie im korzystania z demokratycznych swobód (Priorytety polskiej polityki zagranicznej 2012-2016, 2012, s. 3-5; Skrzypek, 2016, s. 5-41). Dziś pilnym wyzwaniem jest konieczność ścisłej współpracy państw członkowskich UE w celu przezwyciężenia negatywnych skutków kryzysu finansowego i gospodarczego oraz tzw. kryzysu uchodźczego. Ideałem byłoby stworzenie sprawnych i skutecznych mechanizmów chroniących UE przed podobnymi problemami w przyszłości. Znalazło to wyraz w „Deklaracji Rzymskiej”, przyjętej 25 marca 2017 roku podczas szczytu 27 krajów UE z okazji 60. rocznicy podpisania traktatów rzymskich. W dokumencie tym jest mowa o „bezprecedensowych wyzwaniach” dla Unii - od terroryzmu, przez rosnącą presję migracyjną oraz protekcjonizm, aż po nierówności społeczne i ekonomiczne. Przywódcy UE zobowiązali się do budowania Europy bezpiecznej (m.in. z dobrze chronionymi granicami zewnętrznymi), dostatniej, socjalnej (m.in. walczącej z dyskryminacją, wykluczeniem społecznym i ubóstwem) oraz „Europy silniejszej pozycji” w kontekście globalnym (m.in. wzmacniającej obronność we współpracy z NATO). „Europa to nasza wspólna przyszłość” - brzmi ostatnie zdanie 
w tej „Deklaracji” (Deklaracja Rzymska, 2017, s. 9; Bielecki, 2017, s. 9). Niestety, deklaracja ta nie zawiera konkretnych reform, a więc dopiero z czasem się okaże, czy pozostanie czysto okolicznościowym dokumentem, czy też jej zobowiązania będą wypełnione konkretną treścią i reformami.

\section{Unijne plany i koncepcje reform Unii Europejskiej - szanse i zagrożenia dla integracji Europy}

Unia Europejska zastanawia się nad swoją przyszłością już od dawna, a szczególnie od czasu kryzysu w 2008 roku, który pokazał, że nad Europą i światem zbierają się czarne chmury. Unijni przywódcy wiedzą, że głębokie zmiany i reformy w Unii są konieczne. Pierwszego marca 2017 roku przewodniczący Komisji Europejskiej Jean-Claude Juncker zaproponował krajom członkowskim UE w miarę uporządkowaną i spójną koncepcję jej rozwoju. W przedmowie do ogłoszonej wówczas Białej księgi na temat przyszłości Europy napisał: ,stoją przed nami poważne wyzwania dotyczące bezpieczeństwa i dobrobytu naszych mieszkańców oraz przyszłej roli Europy w coraz wyraźniej zarysowanym wielobiegunowym świecie. Zjednoczona Europa skupiająca 27 państw musi wziąć los we własne ręce i zdecydować, jak ma wyglądać jej przyszłość. [...] Podejmując decyzję w wyborze przyszłej drogi, powinniśmy pamiętać, że największe dokonania Europy zawdzięczamy naszej jedności i odwadze w działaniu oraz wierze, że jesteśmy w stanie wspólnie budować naszą przyszłość" (Biała Księga, 2017; President Jean-Clude Junker's, 2017). W dokumencie tym przedstawił aż pięć scenariuszy odnośnie perspektyw rozwoju Unii Europejskiej. M.in. zaproponował większą elastyczność w jej działaniu i rozwiązywaniu problemów oraz skupienie się Unii na priorytetowych obszarach współpracy, w których będzie ona działać szybciej i skuteczniej, a jednocześnie znacznie zmniejszy swoje zaangażowanie w innych obszarach. Tymi obszarami priorytetowymi powinny być innowacje, handel, bezpieczeństwo, migracje i zarządzanie granicami, obronność, dekarbonizacja i cyfryzacja. Jest to wizja Unii ,wielu prędkości”, która powinna umożliwić „koalicjom chętnych” zacieśniać współpracę bez względu na zainteresowanie innych krajów. Zdaniem Komisji Europejskiej, scenariusz ten ma dać największe szanse na zachowanie jedności UE przy utrzymaniu możliwości dalszej integracji, ale może też prowadzić do chaosu i zróżnicowania praw obywateli UE w zależności od tego, z jakiego państwa członkowskiego pochodzą. Według Komisji Europejskiej, państwa pozostające poza priorytetowymi obszarami współpracy będą miały prawo włączenia się w nie w przyszłości (Fiszer, 2018, s. 54).

O niezbędnych dla UE reformach oraz na temat jej nowego kształtu ustrojowego i przyszłości europejskiej integracji, przywódcy Unii wypowiedzieli się także w ogłoszonej 25 marca 2017 roku „Deklaracji przywódców 27 państw członkowskich oraz Rady Europejskiej, Parlamentu Europejskiego i Komisji Europejskiej”, krótko nazywanej ,deklaracją rzymską". Niestety, w deklaracji tej także nie zaproponowano konkretnych dla UE reform. Raczej była ona typowo okolicznościowym dokumentem, w którym zwrócono uwagę na potrzebę przygotowania konkretnych zmian i reform dla UE. 
Zamiast zdecydowanych działań, pół roku później, 13 września 2017 roku przewodniczący J.-C. Juncker wygłosił kolejne „Orędzie o stanie Unii Europejskiej”, w którym raz jeszcze podkreślił, że UE musi zrobić ogromny krok naprzód, jeśli chodzi o demokrację i jej przyszłość (Juncker, 2017; Fiszer, 2017, s. 8). „Nasza przyszłość nie może jednak pozostać zwykłym scenariuszem, szkicem, kolejnym pomysłem. [...] Musimy dokończyć budowę naszego europejskiego domu teraz, dopóki nad nami wciąż świeci słońce. Bo kiedy na horyzoncie znów pojawią się chmury - a pewnego dnia tak się stanie - będzie już za późno" (President Jean-Clude Juncker 's, 2017). W „Orędziu” tym przewodniczący Juncker podkreślił, że nadszedł czas, ,by przejść od refleksji do czynów. Od debaty do podejmowania decyzji” (President Jean-Clude Junker's, 2017).

O stanie UE, jej osiągnięciach i niepowodzeniach oraz zadaniach na przyszłość jest mowa również w kolejnym orędziu szefa Komisji Europejskiej wygłoszonym w 2018 roku, zatytułowanym „Czas europejskiej suwerenności. Łapiąc wiatr w żagle” (Juncker, 2017). W dokumencie tym przewodniczący Juncker podkreślił, że „,będziemy kontynuować nasze wysiłki przez kolejne dwanaście miesięcy, aby z wciąż niedoskonałej Unii Europejskiej czynić co dnia Unię coraz bardziej doskonałą. Pozostaje wiele do zrobienia. [...] W okresie poprzedzającym wybory [wybory do Parlamentu Europejskiego w maju 2019 roku - J. M. Fiszer] powinniśmy udowodnić, że Unia jest w stanie pokonać różnice pomiędzy Północą i Południem, Wschodem i Zachodem, lewicą i prawicą. Europa jest zbyt mała, by się dzielić. Powinniśmy udowodnić, że razem możemy dać początek bardziej suwerennej Europie. [...] Aby to osiągnać, musimy najpierw zaprowadzić porządek we własnym podwórku i wzmocnić naszą unię gospodarczą i walutową, do czego już przystąpiliśmy. Bez pogłębionej unii gospodarczej i walutowej nie mamy wiarygodnych argumentów przemawiających za wzmocnieniem międzynarodowej roli euro. Musimy ukończyć budowę unii gospodarczej i walutowej, aby Europa i euro miały silniejszą pozycję" (Juncker, 2017, s. 7). Obawiam się jednak, że obecne kierownictwo Unii Europejskiej nie jest już w stanie zrobić niczego konkretnego dla wyprowadzenia jej z wspomnianego megakryzysu, w którym tkwi od wielu lat. Częścią owego megakryzysu jest bowiem kryzys przywództwa UE i miałkość jej elit politycznych, które bardziej dbają o własne niż unijne interesy.

W Unii Europejskiej trzeba jak najszybciej zniwelować istniejący trójpodział na państwa członkowskie, instytucje unijne oraz obywateli, który w ostatnich latach uległ zaostrzeniu i stał się jedną z przyczyn postępującej zróżnicowanej integracji. Unia Europejska pilnie potrzebuje nowych elit i nowego przywództwa oraz nowego myślenia i impulsu integracyjnego, a mianowicie, że tylko „ucieczka do przodu” może ją uratować przed rozpadem i zwiększyć jej rolę na arenie międzynarodowej. Zdając sobie z tego sprawę, 9 maja 2019 roku, a więc krótko przed kolejnymi wyborami do Parlamentu Europejskiego, na nieformalnym szczycie w rumuńskim Sybinie szefowie Unii uznali, że trzeba opracować strategiczną agendę reform UE na nadchodzące pięć lat po europejskich wyborach. Chodzi o program działań, jakimi powinny zająć się instytucje europejskie w nowej kadencji, zaczynającej się w listopadzie tego roku. Przyjęta w Sybinie deklaracja zawiera dziesięć zobowiązań, które mają stać się podstawą prac nad bardziej konkretną strategią dla UE. Trzy pierwsze mówią o unijnej jedności: 
30 lat po upadku żelaznej kurtyny UE nie może dać się podzielić na Wschód-Zachód czy Północ-Południe. Zobowiązuje się do szukania w każdej sprawie wspólnych rozwiązań i do wzajemnej solidarności. W kolejnych punktach tej deklaracji przywódcy UE zobowiązali się stać na straży takich unijnych wartości, jak demokracja czy praworządność. Ponadto w deklaracji tej UE obiecuje sprawiedliwość, czy to w polityce społecznej, czy w gospodarce, czy w transformacji cyfrowej. Jeden z kolejnych jej punktów poświęcony został inwestycjom w młodych ludzi i podjęciu wyzwań XXI wieku. Ponadto UE zobowiązała się zająć wyzwaniami globalnymi i bronić opartego na prawie porządku międzynarodowego, wolnego handlu, a także środowiskiem i walką ze zmianami klimatu (Słojewska, 2019, s. A8; Cedro, 2019, s. A14). Program ten z pewnością będzie miał duży wpływ na personalia, na wybór nowego kierownictwa UE, tj. przewodniczącego Komisji Europejskiej, przewodniczącego Rady Europejskiej, przewodniczącego PE, wysokiego przedstawiciela ds. polityki zagranicznej i bezpieczeństwa i prezesa Europejskiego Banku Centralnego. Co więcej, zależnie od ustalonych priorytetów jedni członkowie Komisji Europejskiej będą ważniejsi od innych (Bielecki, 2019, s. A7).

Unia Europejska - co chciałbym zaznaczyć - mimo wielu kryzysów i problemów, także tych związanych z Brexitem, nadal pozostaje największą w świecie wspólnotą, łączącą cechy organizacji międzynarodowej oraz federalnej struktury państwa związkowego. Posiada atrybuty aktora światowego i kompetencje do aktywnego uczestnictwa w stosunkach międzynarodowych. Dysponuje specyficznymi instrumentami, niezbędnymi do działań międzynarodowych, w tym własną dyplomacją. Tego nie wolno zaprzepaścić. UE po majowych wyborach do PE w 2019 roku i po brexicie powinna więc zmierzać nie tylko do utrzymania, ale także do zwiększenia swojej obecności i aktywności we wszystkich regionach świata. Powinna w sposób racjonalny łączyć politykę handlową, pomoc rozwojową i humanitarną z rozszerzającą się działalnością polityczno-dyplomatyczną, tak jak to czynią od lat Stany Zjednoczone i Chiny. Nieodzowna pozostaje konsolidacja strefy euro. Bez unii walutowej nieuniknione będą wewnątrzeuropejskie turbulencje walutowe, jak w latach 80. XX wieku. Załamanie się rynku europejskiego byłoby wówczas nie do uniknięcia. Konsolidacja strefy euro jest także warunkiem wstępnym, by Polska przystąpiła do unii walutowej, spełniając tym samym swoje zobowiązania traktatowe. Absolutnym priorytetem jest dokładne sformułowanie wspólnej polityki zagranicznej, polityki bezpieczeństwa i obrony w obliczu wojen i zagrożeń na wschodzie (w szczególności wobec pogwałcenia status quo w Europie przez Rosję) i na południu od UE oraz niebezpieczeństw, wynikających z terroryzmu islamskiego. Dzięki temu, mimo brexitu, Unia Europejska mogłaby stać się ważnym (Cedro, 2019) stabilizatorem i ośrodkiem politycznego oddziaływania na skalę globalną i wpływać na kształt nowego porządku międzynarodowego, będąc zarazem jednym z jego głównych biegunów. Ale do realnego zwiększenia tego statusu, UE musi się pogłębiać i poszerzać; potrzebuje nie tylko autonomicznego systemu militarno-obronnego, ale również bardziej zdecydowanego przywództwa i akceptowanej przez wszystkich aksjologii.

Duży wpływ na dalsze losy UE będą miały wspomniane wybory do Parlamentu Europejskiego w 2019 roku i wyłonione w ich wyniku nowe jej władze. Od ich wyniku będzie zależała jej przyszłość i szanse dla europejskiej integracji. Dziś trudno 
przewidzieć, czy UE uda się wyjść z megakryzysu, w którym tkwi od kilku lat. Spośród wielu kryzysów - moim zdaniem - dwa miały największy, negatywny wpływ dla UE i jej obecnej sytuacji. Mianowicie kryzys w strefie euro (2008-2012) i kryzys migracyjny (2014-2016) (Grosse, 2018; Wierzchowska, 2016). Spowodowały one głębokie rozczarowanie społeczne do integrującej się Europy i doprowadziły do głębokich podziałów w Unii Europejskiej. Kryzysy te zostały źle zdiagnozowane i co gorsze, metody ich rozwiązywania nie były trafnie dobrane. Dyktat niemiecko-francuski przyniósł opłakane skutki polityczne i międzynarodowe dla UE. Naraził też obywateli takich państw, jak Grecja, Włochy, Hiszpania i Portugalia na duże koszty społeczne, co sprzyja narastaniu tendencji eurosceptycznych, populizmowi i nacjonalizmowi w całej Unii. Niejednokrotnie dochodziły i nadal dochodzą do głosu interesy partykularne nie zaś myślenie o odpowiedzialności za całą Unię Europejską i jej przyszłość. Nie pozostały one też bez wpływu na funkcjonowanie UE na arenie międzynarodowej. W 2018 roku kryzysy w UE zostały przygaszone, ale nie do końca rozwiązane w sposób systemowy. To spowoduje, że już w najbliższych latach mogą pojawić się w UE jeszcze większe problemy społeczne, ekonomiczne i polityczne, a to może doprowadzić do jej rozpadu. Europa utraci wówczas wszystko to, co z takim trudem budowała przez ostatnie sześćdziesiąt lat (Fiszert, 2018, s. 54-78; Wojtaszczyk, Nadolska, 2015; Zielonka, 2014; Grosse, 2018, s. 85-112; Gniffke, 2018, s. 208-123).

Musimy jednak pamiętać, że żyjemy w świecie coraz bardziej zglobalizowanym i dynamicznie zmieniającym się, niosącym nowe zagrożenia i wyzwania. W naszym więc narodowym interesie jest ustanawianie wspólnych dla całej UE wartości, zasad i norm oraz ich przestrzeganie. Z drugiej strony, przekazaliśmy Wspólnocie już sporą część praw i dlatego mamy prawo oczekiwać solidarnego, podmiotowego i równego traktowania. Co więcej, przekazaliśmy je nie tylko organom, w których jesteśmy reprezentowani, ale też niezależnemu organowi, tj. Komisji Europejskiej. Dzisiaj ogromna większość obywateli naszego kraju ocenia to pozytywnie, ale zarazem oczekuje, aby Komisja Europejska i inne jej organy traktowały nas podmiotowo, a nie przedmiotowo. Ważne jest, abyśmy zachowali swobodę decydowania o następnych reformach, które są niezbędne dla dalszego rozwoju UE oraz umocnienia miejsca i roli w niej suwerennej i demokratycznej Polski.

Tutaj warto przypomnieć, że Unia Europejska nie jest państwem i zapewne nigdy nim nie będzie, natomiast to państwa powołały do życia Unię oraz decydują o jej charakterze i determinują jej działalność. Państwa członkowskie, także Polska, są podmiotami pierwotnymi, a UE jest podmiotem wtórnym i pełni wobec nich służebną rolę. Państwa mogą istnieć bez UE lub dobrze funkcjonować poza Unią, ale Unia Europejska nie może funkcjonować bez państw członkowskich. Już ten fakt pokazuje, jak ważne jest miejsce i rola każdego państwa narodowego w Unii Europejskiej. Zarazem chciałbym podkreślić, że mimo wielu mankamentów, Unia Europejska - wbrew niektórym opiniom - nie jest tylko „wyimaginowaną wspólnotą", która Polsce nic nie dała. Jest wspólnotą realną, funkcjonującą na arenie międzynarodowej już dwadzieścia sześć lat. To dzięki niej i NATO od ponad sześćdziesięciu lat w Europie panuje pokój. UE gwarantuje nam bezpieczeństwo ekonomiczne, a NATO bezpieczeństwo militarne. Unia Europejska powinna być nadal dobrowol- 
nym związkiem demokratycznych i suwerennych państw narodowych. Co więcej, podobnie jak NATO powinna być oparta na wspólnych wartościach i interesach. Unia Europejska wymaga jednak głębokich reform, nowej aksjologii, odbiurokratyzowania i w przyszłości powinna służyć nie tylko elitom politycznym, ale przede wszystkim obywatelom państw członkowskich.

\section{Zakończenie}

Konkludując powyższą analizę muszę stwierdzić, że dziś trudno odpowiedzieć na pytanie, jaką organizacją UE będzie w przyszłości? Nie wiadomo też czy nadal jej głównym celem będzie integracja Europy. Po wynikach majowych wyborów do Parlamentu Europejskiego, które wbrew obawom nie wygrali nacjonaliści, populiści i eurosceptycy, Unia Europejska nie rozpadnie się i raczej będzie kontynuowała politykę na rzecz integracji Europy i jej bezpieczeństwa. Podzielam optymizm byłego komisarza UE Janusza Lewandowskiego, który uważa, że po wyborach w maju 2019 roku do Parlamentu Europejskiego w „Unii będzie więcej ciągłości niż zmiany. Nie trzeba wymyślać UE na nowo. Unia pozostanie projektem otwartym na nowe wyzwania. Wyszło z mody definiowanie kształtu docelowego integracji, tzw. «finalite». Liderzy zjednoczonej Europy będą odpowiadali na skromniejsze pytania: ile jeszcze trzeba politycznej, unijnej nadbudowy, by lepiej funkcjonowała unia walutowa, by lepiej zarządzać migracją i obronić rolę globalnego gracza. Wcześniej integracja europejska pogłębiała się poprzez przełomowe traktaty, takie jak Maastricht czy lizboński. Teraz będzie szukała rozwiązań beztraktatowych z uwagi na pamięć bolesnych porażek w referendach krajowych. UE będzie mniej zajęta własnymi instytucjami, ich udoskonaleniem czy psuciem, a bardziej przestrzeganiem reguł i wartości, na których ta wspólnota została zbudowana” (Nizinkiewicz, 2019, s. A6).

Sądzę, że w praktyce Unia Europejska będzie ewoluowała w kierunku „unii ojczyzn", będzie bardziej międzyrządową niż wspólnotową, mniej solidarną i będzie w niej więcej napięć i konfliktów, a decyzje będą podejmowane na zasadzie konsensusu, który będzie trudny do osiągnięcia. W procesie decyzyjnym UE, zwłaszcza po brexicie, główną rolę nadal będzie odgrywał niemiecko-francuski tandem, do którego powinna aktywnie włączyć się Polska. W ten sposób w unijnej polityce dużą rolę mógłby odgrywać Trójkąt Weimarski.

Wybory majowe do Parlamentu Europejskiego pokazały, że UE jest ważna i potrzebna Europie, także Polsce. Jest niezbędna dla integracji Europy oraz dla naszego dobrobytu i bezpieczeństwa jej obywateli. Dlatego też przywódcy Unii już dziś powinni myśleć o nowym traktacie dla niej, o reformach nie tylko jej polityk, ale także głębokiej reformie ustrojowej (systemowej). Trzeba zamknąć sprawy, które dzielą, i skupić się na tym, co łączy, co jest ważne dla państw i ich obywateli, dla Europy i świata (Woźniak, 2019, s. A 26).

Konkludując, należy podkreślić, że UE - jak pokazują to jej dzieje, a zwłaszcza minione piętnaście lat od jej największego rozszerzenia w 2004 roku - jest niezbędna dla Europy i świata oraz dla Polski. Akcesja Polski do UE 1 maja 2004, mimo wielu obaw 
i strachów, opłaciła się. Pod względem gospodarczym nasz kraj mocno skorzystał na wejściu do UE. Poziom zamożności Polski, to dziś $70 \%$ średniej Unii, podczas gdy 1 maja 2004 roku był niższy od 50\%. Polsce sukcesywnie udaje się nadrabiać dystans rozwojowy wobec Zachodniej Europy, choć nie jest najszybsza w tym pościgu. Szybciej Unię gonią dziś Rumunia, Litwa czy Estonia (Cieślak-Wróblewska, 2019, s. 1). Mimo to korzyści z akcesji są dla Polski olbrzymie. Z dnia na dzień rośnie poziom życia Polaków, zmniejsza się różnica w wynagrodzeniach. Według różnych badań sondażowych dziś aż 91\% Polaków deklaruje, że członkostwo w Unii Europejskiej jest korzystne dla Polski, ponad $62 \%$ badanych deklaruje, że Polska zdecydowanie zyskuje na członkostwie w UE, a jedynie niespełna $7 \%$ wypowiada się negatywnie na temat naszego członkostwa w UE (Wiśniewski, 2019, s. A12). Polska jest traktowana jako mocarstwo w naszym regionie i cieszy się szacunkiem na arenie międzynarodowej, podobnie jak cała Unia Europejska, mimo pewnych trudności i problemów. Jest nadal suwerenna i bezpieczna. Stabilizująca rola odgrywana przez Unię Europejską pomogła przemienić większość Europy z kontynentu wojen w kontynent pokoju. Tego nie wolno zaprzepaścić. Unia Europejska może nadal być ważnym stabilizatorem i ośrodkiem politycznego oddziaływania na skalę globalną i wpływać na kształt nowego porządku międzynarodowego, będąc zarazem jednym z jego głównych biegunów. Do realnego zwiększenia tego statusu, UE musi się jednak systematycznie pogłębiać i poszerzać; potrzebuje nie tylko autonomicznego systemu militarno-obronnego, ale również bardziej zdecydowanego przywództwa.

Warto uświadomić sobie, że każda debata nad przyszłością Unii Europejskiej, która przeżywa dziś poważny kryzys, jest jednocześnie debatą nad kierunkiem dalszego rozwoju Polski i jej polityki zagranicznej oraz miejscem na kontynencie europejskim. Dlatego Polska powinna uczynić wszystko co w jej mocy, aby Unia przezwyciężyła kryzys polityczny i gospodarczo-finansowy oraz imigracyjny i wróciła na drogę konsolidacji oraz pogłębiania i poszerzania. Jednocześnie Polska musi prowadzić realistyczną, mądrą politykę międzynarodową, opartą na współpracy ze wszystkimi krajami, a szczególnie z sąsiadami, tak małymi, jak i dużymi. Ogromne znaczenie dla przyszłości naszego kraju, a także dla stabilności całego kontynentu, mają procesy zachodzące $w$ tych krajach, które położone są między wschodnią granicą UE a Rosją. Musimy uczynić wszystko, co w naszej mocy, aby był to obszar stabilności i pomyślności, z sukcesami demokracji, rządów prawa, wolnorynkowych reform gospodarczych. Od tego zależy geopolityczny i cywilizacyjny kształt naszego regionu, a także szanse dalszej europejskiej integracji i trwałego pokoju na naszym kontynencie (Nowak-Jeziorański, 2005, s. 9-11).

\section{Bibliografia}

Ágh A. (2016), The Rocky Road of Europeanization in the New Member States: From the Democracy Capture to the Second Try of Democratization, „Polish Sociological Review”, no. 1(93).

Biała Księga w sprawie przyszłości Europy. Refleksje i scenariusze dotyczace przyszłości UE-27 do 2025 roku (2017), Komisja Europejska, Bruksela.

Bielecki T. (2017), Rzymska wiosna w Unii Europejskiej, „Gazeta Wyborcza”, 27.03.2017.

Bielecki J. (2019a), Polska na ratunek Unii, „Rzeczpospolita”, 21.05.2019. 
Bielecki J. (2019b), Tylko szalony Johnson może uratować torysów, „Rzeczpospolita”, 18.06.2019. Bielecki J. (2019c), Pięć lat na odbudowę zaufania do Brukseli, „Rzeczpospolita”, 21.05.2019.

Brexit to wyprawa w nieznane. Rozmowa z Corneliusem Ochmanem (2017) „Gazeta Wyborcza”, 30.03.2017.

Cieślak-Wróblewska A. (2019), Polski bilans dodatni. 15 lat w Unii Europejskiej, „Rzeczpospolita”, 30.04-1.05.2019.

Co Polacy myśla o Unii Europejskiej? Wnioski z debat w roku 2018 (2019), Komisja Europejska Przedstawicielstwo w Polsce, Warszawa.

Czaputowicz J. (2007), Teorie stosunków międzynarodowych. Krytyka i systematyzacja, Wydawnictwo Naukowe PWN, Warszawa.

Czarnecki M. (2019), Johnson na finiszu, „Gazeta Wyborcza”, 21.06.2019.

Cedro M. (2019), Szczyt wolny od brexitu, „Dziennik Gazeta Prawna”, 9.05.2019.

Czepiel A. P. (2016), Europa dwóch prędkości uratuje Unię, Obserwator finansowy.pl, www.obserwatorfinansowy.pl/tematyka/makroekonomia/euro, 9 lipca 2016.

Czyż A. (2018), Wspótpraca regionalna państw Grupy Wyszehradzkiej. Doświadczenia i perspektywy, Wydawnictwo Uniwersytetu Śląskiego, Katowice.

Deklaracja Rzymska (2017), „Gazeta Wyborcza”, 27.03.2017.

Finkelstein L. S. (1995), What is global governance, "Global Governance", no. 1.

Fiszer J. M. (2018), Unia Europejska po brexicie, w: Unia Europejska - Chiny w XXI wieku, red. J. M. Fiszer, Instytut Studiów Politycznych PAN, Warszawa.

Fiszer J. M. (2016), Efekty transformacji ustrojowej i integracji państw Europy Środkowo-Wschodniej z Unia Europejska, „Myśl Ekonomiczna i Polityczna”, nr 2(53).

Fiszer J. M. (2018), Niemcy i Francja w Unii Europejskiej po brexicie, „Rocznik Polsko-Niemiecki”, nr 26.

Fiszer J. M. (2017), Perspektywy Unii Europejskiej po Brexicie i jej rola w nowym ładzie globalnym, „Biuletyn Analiz i Opinii”, Zakład Europeistyki ISP PAN, nr 04.

Fiszer J. M. (2018), Pozytywne i negatywne aspekty działalności państw Grupy Wyszehradzkiej w latach 1991-2018, „Myśl Ekonomiczna i Polityczna”, nr 4(63).

Fiszer J. M. (2018), Megakryzys w Unii Europejskiej - istota, przesłanki i implikacje dla integracji Europy w drugiej dekadzie XXI wieku, w: Kryzysy w Unii Europejskiej w drugiej dekadzie XXI wieku. Uwarunkowania - przebieg - implikacje, red. T. Kubin, M. Stolarczyk, Wydawnictwo Uniwersytetu Śląskiego, Katowice.

Gniffke A. (2018), (Wann) Kommt die Finanzkrise wieder?, „Myśl Ekonomiczna i Polityczna”, $\mathrm{nr} 4(63)$.

Grosse T. G. (2018), Pokryzysowa Europa. Dylematy Unii Europejskiej, Polski Instytut Spraw Międzynarodowych, Warszawa.

Grosse T. G. (2017), Changes in EU common market in the aftermath of ther crisses, „Studia Polityczne", nr 3, tom 46.

Jak refren powraca wizja Rosji mocarstwowej, upokarzanej i zdradzonej przez Zachód (2019), Wywiad Magdaleny Cedro z Jolantą Darczewską, analitykiem Ośrodka Studiów Wschodnich, „Dziennik Gazeta Prawna”, 16.05.2019.

Juncker J.-C. (2017), Orędzie o stanie Unii 2017, Komisja Europejska, Bruksela.

Kolonko M. (2019), Kampania na ostatniej prostej, „Rzeczpospolita”, 20.05.2019, s. A3.

Lang K. O. (2019), W interesie Niemiec jest, żeby Polska była bezpieczniejsza, „Dziennik Gazeta Prawna", 12.06.2019.

Nizinkiewicz J. (2019a), PiS staje się obiektem pożądania, „Rzeczpospolita”, 10.05.2019. 
Nizinkiewicz J. (2019b), Rządy PiS to niezdeklarowany polexit. Unia zawadza Kaczyńskiemu w urządzaniu Polski po swojemu - twierdzi Janusz Lewandowski z Komisji Europejskiej, „Rzeczpospolita”, 14.05.2019.

Nowak-Jeziorański J. (2005), Rzeczpospolita atlantycka. Czym jest polska racja stanu?, w: Polska polityka wschodnia, Kolegium Europy Wschodniej, Wrocław.

Osiecki G., Żółciak T. (2019), Szanse na pozytywne zmiany w Unii. Wywiad z Beatą Szydło, „Dziennik Gazeta Prawna", 20.05.2019.

Pełczyńska-Nałęcz P. (2019), Praworząność w Unii poza politycznymi podziałami. Sankcje budżetowe i nowy program dla obywateli, Fundacja im. Stefana Batorego, Warszawa.

President Jean-Claude Juncker's State of the Union Address (2017), European Kommision - Speech, EN-FR-DE-Speech, pdf.

Priorytety polskiej polityki zagranicznej 2012-2016 (2012), Ministerstwo Spraw Zagranicznych, Warszawa.

Rezolucja Parlamentu Europejskiego (2017) z dnia 16 lutego 2017 r. w sprawie poprawy funkcjonowania Unii Europejskiej dzięki wykorzystaniu potencjału Traktatu z Lizbony (2014/2249(INI)).

Schulz M. (2014), Skrępowany OLBRZYM. Ostatnia szansa dla Europy, MUZA SA, Warszawa.

Siemionczyk G. (2019a), Integracja europejska zostanie na starych torach, „Rzeczpospolita”, 28.05.2019.

Siemionczyk G. (2019b), Czas skończyć z unia szantażystów, Wywiad z prof. Markusem C. Kerberem, ,Rzeczpospolita”, 21.05.2019.

Skrzypek A. (2016), Kryzys Unii, idei, polityki?, „Politeja”.

Słojewska A. (2019a), Belgowie też rozczarowani elitami politycznymi, „Rzeczpospolita”, 16.06.2019.

Słojewska A. (2019b), Unijna próba sit, „Rzeczpospolita”, 17.06.2019.

Słojewska A. (2019c), W Sybinie ponad podziałami, „Rzeczpospolita”, 10.05.2019.

Stiglitz J. (2016), Lekcja angielskiego, „Obserwator finansowy.pl”, www.obserwatorfinansowy.p1/ tematyka/makroekonomia/lekcja, 18.07.2016.

„Rzeczpospolita”, 30.05.2019.

Stodolak S. (2017), Europejska gospodarka dusi się w politycznym pacie, „Obserwator finansowy. pl”, 25.04.2017, s. 6, www.obserwatorfinansowy.pl.

Wierzchowska A. (2016), Wplyw modernizacji i kryzysu na dynamike zmiany w Unii Europejskiej, Dom Wydawniczy ELIPSA, Warszawa.

Wiśniewski R. (2019), Europa szanująca tożsamość narodów, „Rzeczpospolita”, 12.04.2019.

Wojtaszczyk K. A., Nadolska J. (2015), Kryzysy w procesie integracji europejskiej i sposoby ich przezwyciężania, Oficyna Wydawnicza ASPRA-JR, Warszawa.

Zielonka J. (2014), Koniec Unii Europejskiej?, Polski Instytut Spraw Międzynarodowych, Warszawa.

\section{Streszczenie}

Niniejszy artykuł poświęcony jest stanowisku władz Unii Europejskiej i jej głównych organów w sprawie koniecznych dla Unii reform, które są niezbędne, aby stała się ona siłą motoryczną w dalszym procesie integracji Europy. Jego celem jest analiza obecnej kondycji UE i zarysowanie perspektyw jej rozwoju. Główne organy Unii, m.in. Komisja i Parlament Europejski oraz Rada Europejska w ostatnich latach zgłosiły wiele różnych strategii i propozycji „,naprawy” UE, ale niewiele z nich zostało wprowadzonych w życie. Unia Europejska 
wciąż dryfuje i traci swój autorytet na arenie międzynarodowej, a integracja Europy przeżywa regres.

W opracowaniu tym stawiam kilka tez, hipotez i pytań badawczych, na które próbuję udzielić w miarę wyczerpujących odpowiedzi. Jedna z tych tez dotyczy wielkiego rozszerzenia UE w 2004 roku, a druga wprowadzenia wspólnej waluty - euro.

Slowa kluczowe: Unia Europejska, Komisja Europejska, Parlament Europejski, deklaracje, integracja Europy

\title{
The concepts of European Union reforms and its position towards the integration of Europe
}

\begin{abstract}
Summary
This article is devoted to the position of the European Union authorities and its main bodies on the reforms necessary for the Union to become a driving force in the further process of European integration. Its aim is to analyze the current EU condition and outline the prospects for its development. The main bodies of the Union, inter alia The Commission and the European Parliament and the European Council have in recent years reported a wide range of EU 'recovery' strategies and proposals but few have been implemented. The European Union is still drifting and losing its authority on the international scene, and European integration is in decline.

In this study, I put a few theses, hypotheses and research questions to which I am trying to give comprehensive answers. One of these also concerns the great enlargement of the EU in 2004 , and the other one introducing the single currency - the euro.
\end{abstract}

Key words: European Union, European Commission, European Parliament, declarations, European integration 
